\title{
Effects of Chronic Simulated Hypobaric Hypoxia on Mouse Spermatogenesis
}

\author{
Efectos de la Hipoxia Hipobárica Simulada Crónica sobre la Espermatogénesis en el Ratón
}

Eduardo Bustos-Obregón; Christian Esveile; Julio Contreras; Inge Maurer \& Luis Sarabia

BUSTOS-OBREGón, E.; ESVEILE, C.; CONTRERAS, J.; MAURER, I. \& SARABIA, L. Effects of chronic simulated hypobaric hypoxia on mouse spermatogenesis. Int. J. Morphol., 24(3):481-488, 2006.

SUMMARY: Reduction of O2 delivery to tissues damage them, including the seminiferous epithelium. Recently, population working in high altitude has increased, so that the study of hypobaric hypoxia on spermatogenesis becomes of interest. In this study we used two groups of male, sexually mature mice Control (C) (540 meters above sea level (masl)) and chronic simulated hypobaric hypoxia (CSHH) (4,600 masl) exposed during 8, 16, 24 or 33 days. Hematocrit; reticulocytosis; testicular, epididymal and seminal vesicle weight; seminiferous epithelium height, tubular diameter, sperm count and morphology and testicular parenchyme and spermatozoa membranes lipoperoxidation were measured. Weight of testis, epididymis and seminal vesicle were reduced but they recuperate at 33 days. Tubular diameter and epithelial height are reduced, subsequently they tend to increase without returning to normal values. The count and sperm morphology fluctuate along the exposure time. Lipoperoxidation levels of spermatozoa and testicular parenchyme are reduced. Therefore, we can conclude that exposure to CSHH induce damage in the seminiferous epithelium, decrease of lipoperoxidation in spermatozoa and testicular tissue, and damages the testicular and sperm morphology.

KEY WORDS: Hypoxia; Lipoperoxidation; Mouse; Testis.

\section{INTRODUCTION}

All cells of the body require an adequate oxygen contribution to accomplish their functions adequately and in a coordinate way with the environment in which they are and with other cells. A reduced delivery of this gas may damage tissues (Guyton \& Hall, 1996). In this study we focussed in specific tissues, those of the reproductive male apparatus.

Moreover, population that works or lives in high altitude is increasing nowadays. As elevation above sea level increases total barometric pressure (PB) decreases, as well as parcial pressure of oxygen $\left(\mathrm{PO}_{2}\right)$. This condition of reduced $\mathrm{PO}_{2}$ because of a diminution of $\mathrm{PB}$ is known as hypobaric hypoxia (HH) (Guyton \& Hall; Reeves \& Weil, 2001). In HH multiple physiological processes are affected, for example breath, circulation, intermediary and specific metabolism, and cognoscitive capacity (Guyton \& Hall).

However, human beings and other animals have defenses against $\mathrm{HH}$ such as increasing of respiratory frequency and cardiac output, erythropoeitin (EPO) release, and a concomitant increase of total content of red corpuscles, and thus, of haemoglobin (Guyton \& Hall). Also the activation of a transcription factor has been described that accounts for adaptive mechanisms in tissular hypoxia, ie HIF-1 (hypoxia inducible factor 1). Its activity enhances EPO synthesis, local neoangiogenesis and vasodilation (Bunn \& Poyton, 1996; Giordano \& Johnson, 2001; Semenza, 2003) and anaerobic metabolism (Dang \& Semenza, 1999; Seagrovez et al., 2001). Besides, HIF-1 regulates vasomotricity (Melillo et al., 1995; Nguyen \& Claycomb, 1999) and cellular cycle (Feldser et al., 1999; Krishnamachary et al., 2003).

With respect to the alteration of the reproductive capacity of males, historically the action of $\mathrm{HH}$ has been discussed. The classical studies on this matter have considered experimental conditions imitating extreme altitudes, where human or animal life is limited or even impossible ( Walton \& Urusky, 1946; Attland, 1949). In 1968, Monge \& Monge (1968) showed that mature spermatozoas are not affected by $\mathrm{HH}$, whereas Bustos-Obregon \& Olivares 
described in 1982 a great damage in mature spermatozoa, specially in exposition times above fifteen days. Recently, it has been established that in exposition times to $\mathrm{HH}$ above sixty days, there is morphological injury in the seminiferous tissue, associated to energetic and metabolic alterations in spermatogenic cells (Farías et al., 2005b).

The present work aims to evaluate from a morphologic point of view the effects of chronic simulated hypobaric hypoxia (CSHH) on mouse spermatogenesis, obtained by means of a constant, simulated exposure in a hypobaric chamber of mice to conditions of HH. Seminiferous tubule and spermatic morphology, and lipoperoxidation in spermatozoa and testicular tissue were analized.

\section{MATERIAL AND METHOD}

Animals. Forty CF1 sexually mature (average weight 35,3 \pm $3.0 \mathrm{~g})$ male mice, from the animal room of the Laboratory were used. They were kept at 12:12 h L/D and 22 to $22^{\circ} \mathrm{C}$ and fed commercial pellet and water ad libitum.

The experimental protocol was approved by the Committee of Bioethics for Research of the Faculty of Medicine, University of Chile.

Experimental design. Mice were divided into two groups. Control ( C ) and simulated chronic hypoxia (HHSC). C was subdivided in 4 groups of 4 mice each and so was the HHSC mice ( 6 mice per group). The 4 experimental groups were submitted to a simulated barometric pressure (of $428 \mathrm{~mm}$ Hg (5687 Pa, 4.6000 MSNM, PO = 89,6 mm Hg (11907 Pa) using an hypobaric chamber. Group 1 (HHSC 8) was exposed for 8,3 days, Group 2 (HHSC 16) for 16.6 days, Group 3 (HHSC 24) for 24,9 days and Group 4 (HHSC 33) for 33.2 days, the latter being the time for complete spermatogenesis in mice, whereas 8,3 days is the duration of one cycle of the seminiferous epithelium. The control mice were sacrificed at the same intervals (4 animals per group) and kept at a $\mathrm{Pb}$ of $710 \mathrm{~mm}$ de $\mathrm{Hg}$ (94355 Pa, 540 MSNM ; PO2 $=148,6 \mathrm{~mm} \mathrm{Hg}(19748 \mathrm{~Pa})$ ) which corresponds to the city of Santiago (MSNM meters above sea level).

Experimental procedures. After anesthesia with ketamine, blood was obtained by cardiac puncture with an heparinized syringe for hematocrit and reticulocytes count after Giemsa staining (\% reticulocytes per 400 erythrocytes).

Testes, epididymis and seminal vesicles were dissected out and weighed. One testis was fixed in Bouin for $24 \mathrm{hs}$ and then processed for routine histological procedures, cut at $5 \mathrm{~m} \mu$ and stained with $\mathrm{H}+\mathrm{E}$, to be used for morphometry.

Morphometric analysis. Micrographs were obtained with a OHU (Solid State Camera) using a NIKON Labophot-2 microscope and analyzed using the Image Tool v3.0 program. The mean height of the seminiferous epithelium and tubular diameter were measured in 50 tubules per animal.

Sperm count. Spermatozoa were obtained macerating a piece of cauda epididymis weighed and suspended in PBS and filtered through gauze. An aliquot $(100 \mathrm{~mL})$ was mixed with $100 \mathrm{~mL}$ of $10 \%$ formaldehyde and $15 \mathrm{~mL}$ were charged in a Neubauer chamber for sperm counting.

Sperm morphology. $15 \mathrm{~mL}$ of the fixed sperm were smeared on a glass slide, dried at room temperature and stained with $\mathrm{H}+\mathrm{E}$.

Two hundred sperm per mice were examined under light microscopy (1000 X) to assess head and tail defects (Vigil \& Bustos-Obregón, 1985).

Lipoperoxidation determination. Calibration curve. Seven tubes are prepared as follows :

\begin{tabular}{cccc}
\hline Tube $^{\mathbf{0}}$ & $\begin{array}{c}\text { Final Concentration } \\
(\mathbf{m M})\end{array}$ & $\begin{array}{c}\text { MDA Solution } \\
\mathbf{0 . 0 1} \mathbf{~ m M}(\boldsymbol{\mu L})\end{array}$ & $\begin{array}{c}\text { TCA 5\% } \\
(\boldsymbol{\mu L})\end{array}$ \\
\hline 1 & 0.3 & 75 & 1925 \\
2 & 0.75 & 150 & 1850 \\
3 & 1.5 & 300 & \\
4 & 3.0 & 600 & 1400 \\
5 & 6.0 & 1200 & 800 \\
6 & 8.0 & 1600 & 400 \\
7 & 10.0 & 2000 & 0 \\
\hline
\end{tabular}

After shaking the tubes, $700 \mathrm{~mL}$ of solution are mixed with $1300 \mathrm{~mL}$ of thiobarbituric acid (TBA) $0.67 \%$. Control is done with $700 \mathrm{~mL}$ trichloroacetic acid $5 \%$ and $1300 \mathrm{~mL}$ of TBA $0.67 \%$. All tubes are sealed with aluminum paper, put for $20 \mathrm{~min}$ in a water bath at $100^{\circ} \mathrm{C}$, then cooled for 5 min in ice and read at $535 \mathrm{~nm}$ in a spectrophotometer.

Testicular fluid and seminiferous epithelium cells. $5 \mathrm{mg}$ of testicular tissue are macerated in $1 \mathrm{ml}$ of PBS. Then $50 \mathrm{~mL}$ of ferrous sulfate $1 \mathrm{mM}$ and $25 \mathrm{~mL}$ of sodium ascorbate $10 \mathrm{mM}$ are added. The mixture is incubated for one hour. 
Spermatozoa. Samples with approximately of 5 x 106 sperm/ $\mathrm{ml}$ were diluted in PBS up to $1 \mathrm{ml}$ and then $50 \mathrm{~mL}$ ferrous sulfate and ascorbate were added as above. The mixture was incubated for one hour at $37^{\circ} \mathrm{C}$.

Final Common steps. The reaction of both testicular fluid or sperm was stopped adding $31.2 \mathrm{~mL}$ of TCA $100 \%$ to each tube. The tubes were cooled in ice for $20 \mathrm{~min}$ and then centrifuged at $1500 \mathrm{~g}$ for $10 \mathrm{~min}$. The supernatant was again centifuged at $1500 \mathrm{~g}$ for $10 \mathrm{~min} .700 \mathrm{~mL}$ of supernatant was obtained and $1300 \mathrm{~mL}$ of TBA $0.67 \%$ was added. The tubes were covered with aluminum foil, heated in a water bath at $100^{\circ} \mathrm{C}$ for $20 \mathrm{~min}$ and then cooled in ice for $5 \mathrm{~min}$ to read absorbance at $535 \mathrm{~nm}$.

Statistical analysis. Normality of the data was checked using the Shapiro-Wilk test. If diatribution was normal, then the t-test was used. If not, the Mann-Whitney test was employed. Significance was set at $\mathrm{p} \leq 0.05$. All graphs represent the mean \pm S.D.

\section{RESULTS}

Reticulocytary count and hematocrit (Fig. I). An increase of nearly $300 \%$ of the quantity of circulating reticulocytes was appreciated in $\mathrm{CSHH} 8$ group, with respect to $\mathrm{C}$ group. This altered value is conserved in CSHH 8, CSHH16 and $\mathrm{CSHH} 24$. In the CSHH33 group there was an even higher value in comparison to the other groups.

There also was an increase about $50 \%$ of the hematocrit in the CSHH8 group with respect to $\mathrm{C}$ group. Something similar happened to the other groups.

Fig. 1. SCHH provokes an increase in hematocrit and reticulocytes.

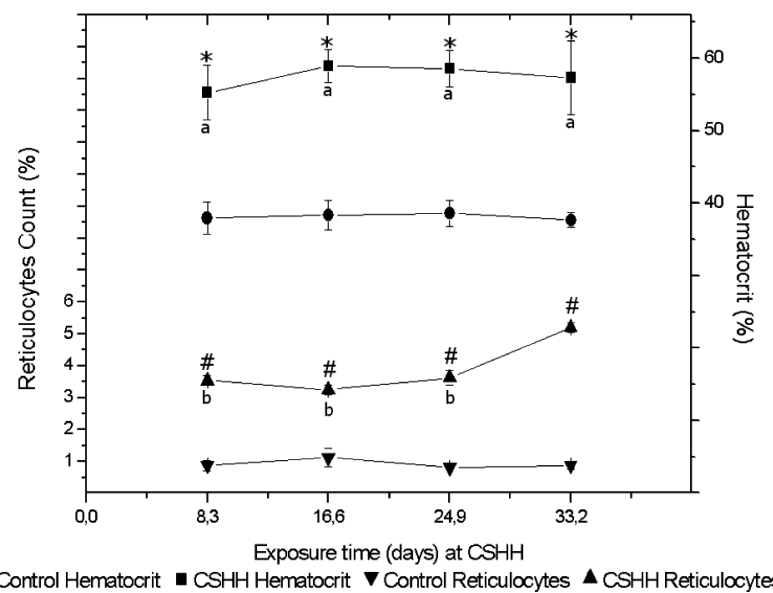

In Figures 1 to $6 \mathrm{n}=4$ for controls; $\mathrm{n} 6$ for experimental groups. a,b: no statistical difference. $(*) \mathrm{p}<0.005$. (\#) $<0.001$. SCHH : Simulated Chronic Hypobaric Hypoxia.

Testicular and epidydimal weight (Fig. 2). In CSHH8 group we did not observe changes in testicular weight with respect to $\mathrm{C}$ group. In CSHH16 and CSHH24 groups there was a diminution in testicular weights, the smaller measurement was foundin the latter, while in CSHH33 group a significative increment of testicular weight was seen.

Epidydimal weights in CSHH8 group were normal. Nevertheless, in CSHH16 and CSHH24 weights registered were lesser than $\mathrm{C}$ group. On the other hand, epididymal weights of CSHH33 group were significantly greater.

Fig. 2. Testicular and epididymal weight in control and SCHH mice after different intervals of exposure $(\mathrm{X} \pm \mathrm{SE})$.

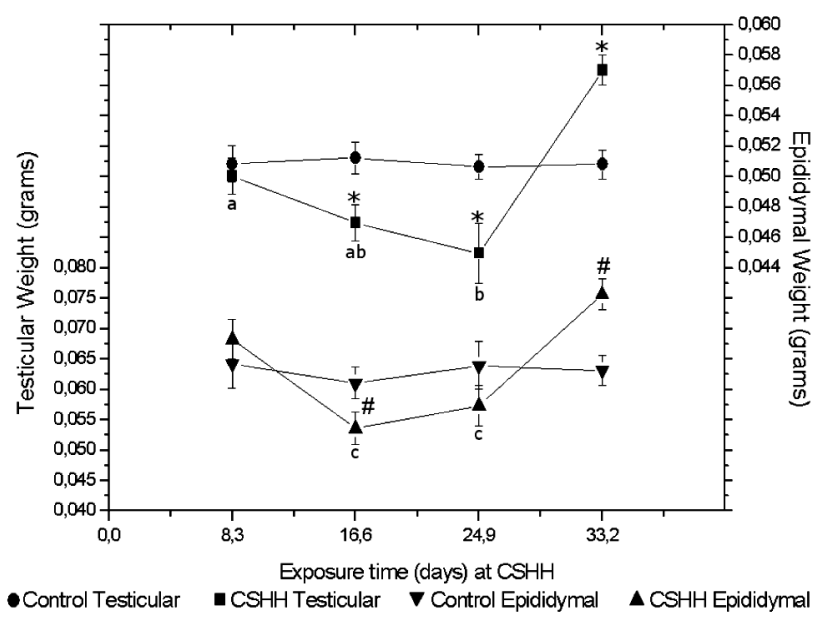

Epididymal cauda and seminal vesicle weights (Fig. 3). There were no variations in epidydimal cauda weights of CSHH8 group with respect to the $\mathrm{C}$ group. The group HHSC16 shows a significant decrease compared to $\mathrm{C}$, whereas HHSC33 increases respect to HHSC24, which slighlty excedes grroup C. The group HHSC is lower than the group HHSC8.

Seminal vesicles weight. Group HHSC8 is not different from C. In group HHSC16 there is a significant decrease as well as in HHSC24. The group HHSC33 is not different from C.

Morphometric analysis (Fig. 4). Tubular diameter. At all intervals, testicular diameter was lower than C. being lowest at 8 days. Epithelial height. Evolves very similar to tubular diameter without complete recuperation by 33 days. 
Fig. 3. Cauda epididymis and seminal vesicle weights vary in a similar way after exposure.

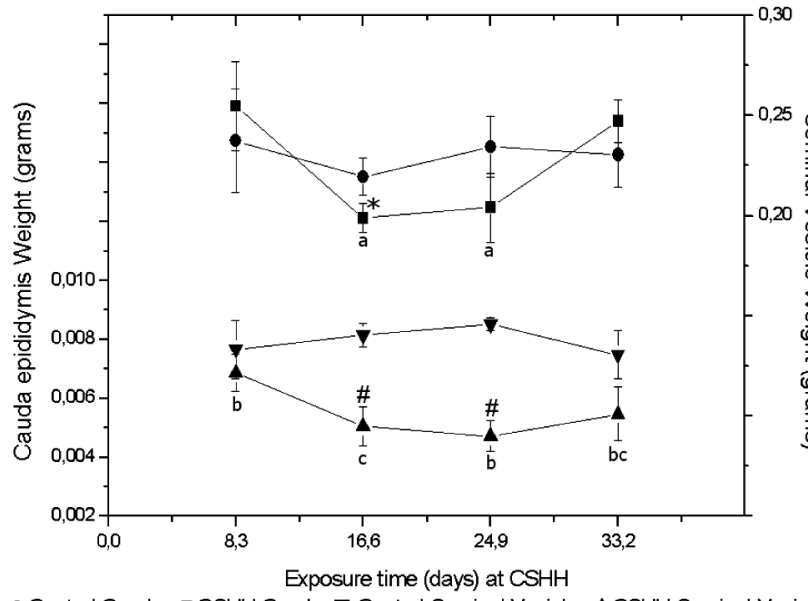

- Control Cauda - CSHH Cauda $\mathbf{V}$ Control Seminal Vesicle $\Delta$ CSHH Seminal Vesicle

Fig. 4. The height of the seminiferous epithelium and tubular diameter decrease after SCHH exposure.

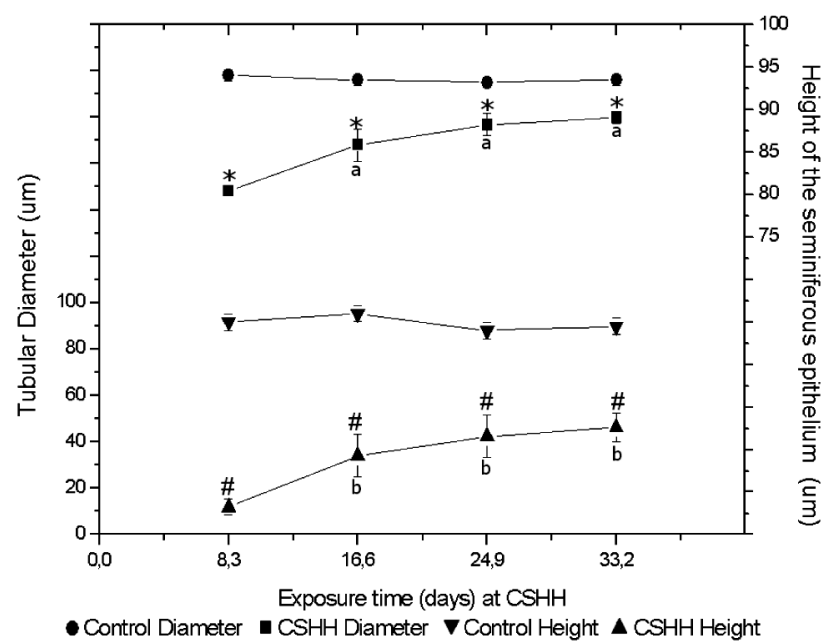

Teratozoospermia and sperm count (Fig. 5). At 16 and 33 days it increases compared to $\mathrm{C}$ but it is not different from $\mathrm{C}$ at 8 and 24 days. At 33 days high teratozoospermia was observed.

Sperm count. No major variations were found.

Lipoperoxidation of testicular parenchyma and spermatozoa (Fig. 6).

Lipoperoxidation of testicular parenchyma. Data show a $34 \%$ decrease at 8 days compared to $\mathrm{C}$, no change at 16 days and a decrease at 24 and 33 days.

Lipoperoxidation of spermatozoa. At 8 days there is no difference to $\mathrm{C}$. At 8,16 and 33 days there is a decrease compared to $\mathrm{C}$.
Fig. 5. Sperm count is kept nearly unchanged but teratozoospermia increases and fluctuates after SCHH exposure.

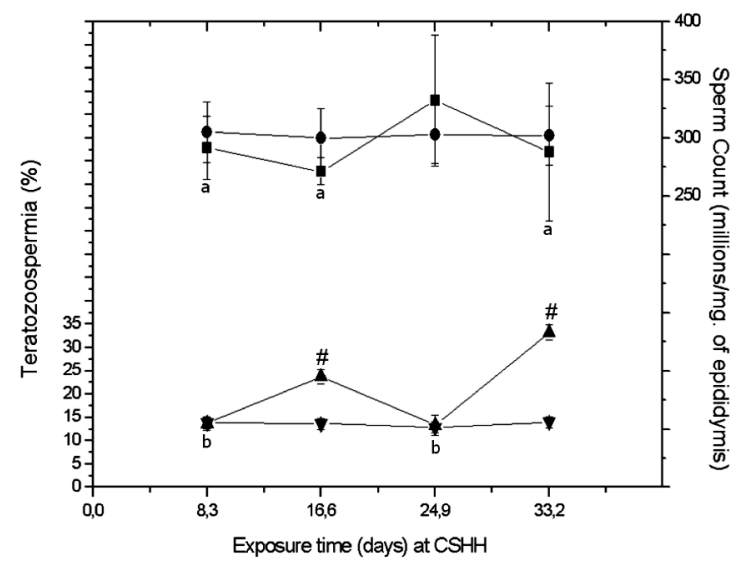

Fig. 6. Lipoperoxidation of testicular parenchyme and spermatozoa decreases after $\mathrm{SCHH}$ exposure.

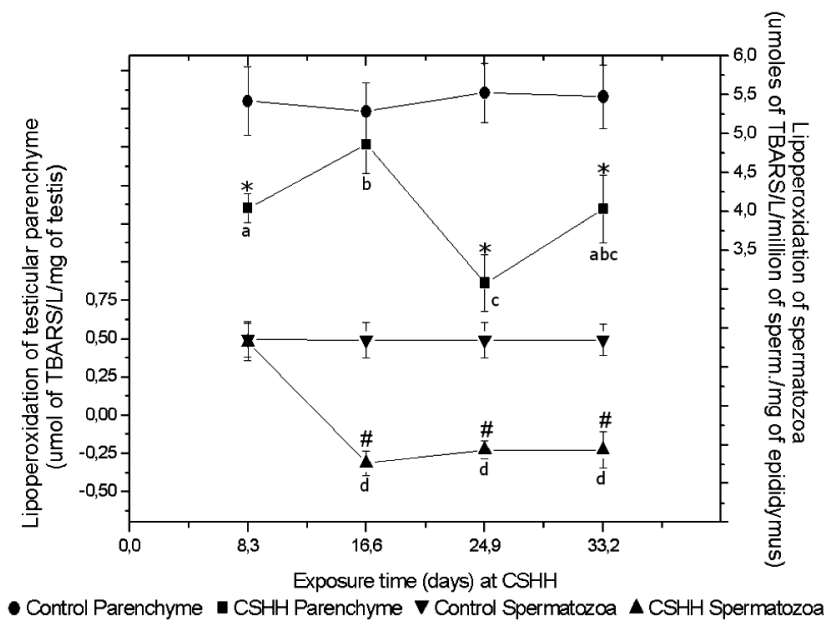

Testicular histopathology (Figs. 7, A-J).

The most relevant tissular changes are seen by 8 days. They include cell sloughing and blockage of the lumen, disarrangement of the seminiferous epithelium, vacuolization and cell loss. No evident apoptotic elements were found. These changes diminish by 33 days but tubular blockage is seen all along. Evidence of neoangiogenesis, increasing with time, was also noticed. 


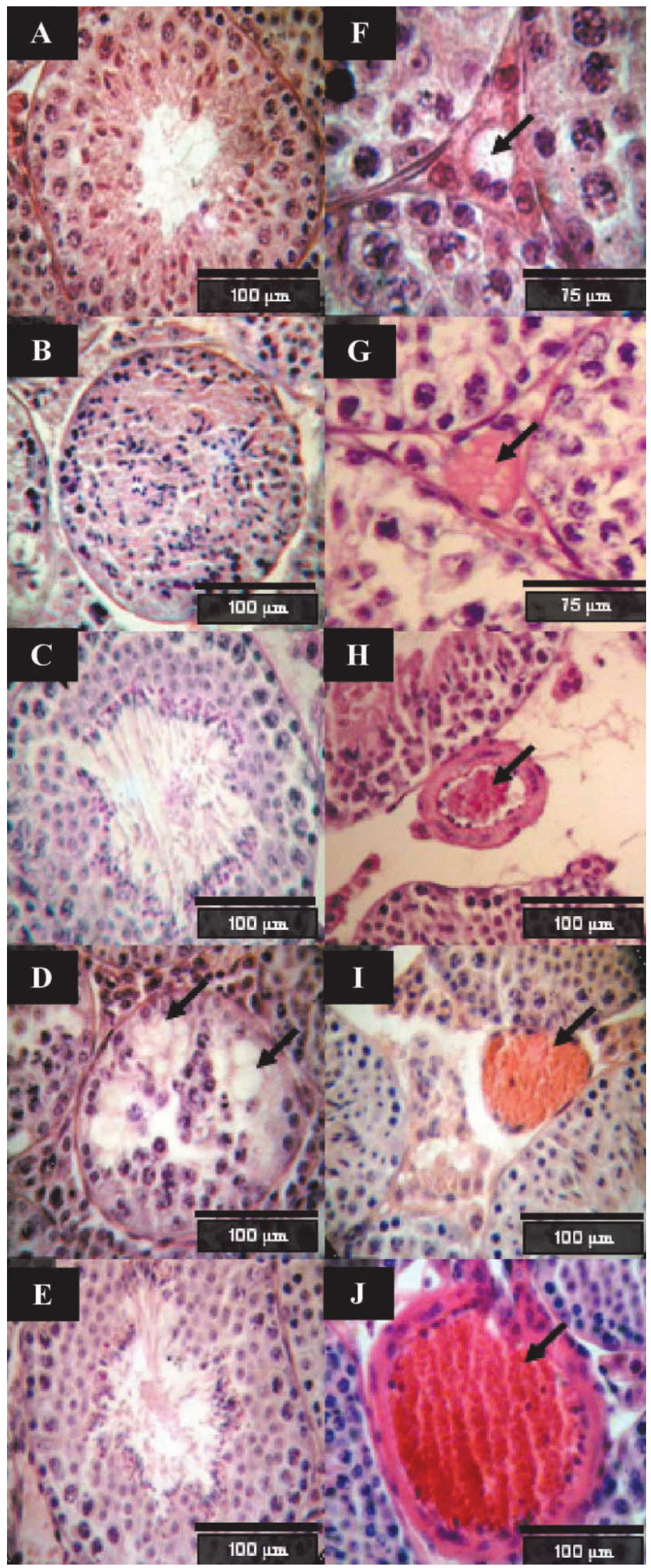

Fig. 7. Under exposure to $\mathrm{SCHH}$ there is damage to the seminiferous tubules and gradual increase of neoangiogenesis and vasodilation (bar $100 \mathrm{m \mu} \mathrm{A-}$ E; I, J and $75 \mathrm{~mm} \mathrm{F-G).} \mathrm{(SCHH} \mathrm{:} \mathrm{Chronic}$ stimulated hypobaric hypoxia.

A.Control seminiferous tubule with normal histology.

B. SCHH 8 days. Tubular blockade, germ cell disarrangement, enlargement of the interstitial space and decreased tubular diameter.

C. SCHH 16 days. Diminished epithelial height.

D. SCHH 24 days. Extense vacuolization of the seminiferous epithelium, luminal blockade and cell loss (arrows).

E. SCHH 33 days. Morphology of the seminiferous tubules is normalized.

F. Control. Normal capillary (arrow) in the insterstitial space.

G. SCHH 8 days. Dilated neoformed capillary (arrow) by 8 days of SCHH.

H. SCHH 16 days. Dilated small arteriole (arrow) in the intertubular space by 16 days of SCHH.

I. SCHH 24 days. A large venule is seen (arrow).

J. SCHH 33 days. In the interstitium a large arteriole, never seen in controls, is however still present (arrow). 


\section{DISCUSSION}

According to the findings of this work the most sensitive male reproductive element is the seminiferous epithelium. This is perhaps due to the fact that under physiological conditions their cells are in relative hypoxia due to the height of the epithelium and to the distance of the arterioles and capillaries to the basal membrane. Therefore the $\mathrm{pO}_{2}$ is lower at the apex of the seminiferous epithelium. The seminal vesicles and epididymis are also sensitive to hypoxia and adapt slowly to this condition since they do not have a rich irrigation. Ths testis (as an organ) and the caput adapt more readily (Geneser, 2000), at least during the first days of hypoxia.

Exposure of mice to $\mathrm{SCHH}$ triggers the classical hematological response denoted by increased hematocrit and reticulocytosis, decrease in organ weight, sperm count alterations and increased teratozoospermia (Guyton \& Hall). All these changes may compromise the fertility of the animals (Walton \& Urusky; Farías et al., 2005b).

Animals exposed to high altitude undergo dehydration, that may by itself alter the hematocrit. However, increased reticulocytosis in a clear sign of stimulation of red cell compartment of the bone marrow. At 33 days of $\mathrm{SCHH}$ exposure reticulocytes increase in number whithout a parallel increase in hematocrit. This may correspond to hemodilution due to anoxia of blood vessels (Cao et al., 2004; Ali et al., 1999).

Fluctuations of organ and body weight are difficult to analyze, not only due to this change of corporal fluids in hypoxia but also because feeding of mice may not be normal under SCHH. The evolution of testicular and epididymal weights is remarkable similar, perhaps implying similar reactive mechanisms under hypoxia.

Increase in testicular weight seen by 33 days of $\mathrm{SCHH}$, can be the result of edema. In fact, the interstial space was found to be enlarged.

In addition, higher blood flow and clear signs of neoangiogenesis were observed, which could also account for higher testicular weight. This was not the case for cauda epididymis and seminal vesicles, in agreement with their relatively scarce circulation (Geneser).

Reduction of the epithelial height may be due to decrease in germ cell size, difficult to judge in histological sections, but also to decreased germ cell proliferation due to metabolic restraint imposed by hypoxia. Decrease tubular diameter correlated well with this issue and with the increase in interstitial space.

Morphometry goes along with the histopathological findings in the testis though no clear pattern could be stated for each period of exposure to $\mathrm{SCHH}$.

Sperm count results from two factors: sperm production by the seminiferous epithelium and sperm output through the seminal pathway, where they are stored at the cauda epididymis even for months (Geneser).

Sperm count really is the evaluation of the net average sperm production per cycle (ie. 8,3 days (Clermont, 1972) previous to the count, to which the sperm transit time to the cauda of the epididymis must be added (about 5 days) (Dadoune \& Alfonsi, 1984). Therefore, changes in sperm output will be recorded in cauda by 13,3 days. The absence of such changes after 8 days of $\mathrm{HH}$ should corresponds to the number of sperm already stored in cauda plus those generated from the very late spermatids. They are not affected by $\mathrm{HH}$, since their number and morphology are not altered.

At 16 and 33 days after $\mathrm{HH}$, sperm count is kept but increased teratozoospermia is seen, as HH may disturb differentiation during spermiogenesis and late meiotic stages (Clermont; Geneser).

Bvy 16 days we have total differentiation of sperm cells that come from the first cycle ( 8,3 days) and the same is valid for 24 days, comprising mostly elongated spermatids by the time of $\mathrm{HH}$ exposure and some round spermatids (Clermont; Geneser).

Therefore, $\mathrm{HH}$ seems to affect mainly differentiating spermatogenic cells. Spermatogonia are also affected and their decreased mitotic activity may account for the diminished epithelial height.

Studies similar to the present one (Bustos-Obregón \& Olivares; Farías et al., 2005b) have detected similar morphologic and morphometric changes, such as in BustosObregón \& Olivares.

In sumary, reproductive parameters are altered by HH (Walton \& Urusky; Farías et al., 2005b), with a probable decrease in mice fertility.

Arteriolar vasodilation and neoangiogenesis that were detected at long intervals after HH certainly damage spermatogenesis by increasing testicular temperature, as it has been reported in rats submitted to HH (Farias et al., 2005a). 
Lipoperoxidation of sperm cell membranes relates to oxidative stress of these cells (Griveau et al., 1995). It tends to persist along all differentiation of spermatids due to the scarce cytoplasm of these cells. The amount of reactive oxygen species (ROS) reveals a decreased oxidative stress in $\mathrm{HH}$. These findings have been also reported in other works (Erkkilä et al., 1999).

When oxygen diminishes, as in $\mathrm{HH}$, one expects ROS to decrease in tissues. This has been explained by a lack of activity of the NADPH oxidase which is normally generating ROS. This is a signal in the cells for proteins such as HIF-1 a transcription factor that is constitutively expressed in the cells, but is continously degraded by ubiquitinization in the proteosomes. (Zagórska \& Dulak, 2004).

ROS decrease stabilizes the HIFF, so that the expression of genes related to adaptation to hypoxia increases through proteins that regulate neoangiogenesis and vasodilation, thus increasing anaerobic metabolism and regulating cell cycle among other numerous functions.

Exact knowledge of $\mathrm{HH}$ metabolic effect upon spermatogenic cells will require extensive cell biology appraisal of these basic phenomena, in order to prevent eventual fertility related pathologies due to hypoxia.

BUSTOS-OBREgón, E.; ESVEILE, C.; CONTRERAS, J.; MAURER, I. \& SARABIA, L. Efectos de la hipoxia hipobárica simulada crónica sobre la espermatogénesis en el ratón. Int. J. Morphol., 24(3):481-488, 2006.

RESUMEN: La disminución del aporte de $\mathrm{O}_{2}$ a los tejidos provoca daños de éstos, incluido el epitelio seminífero. Últimamente, se ha incrementado la población que trabaja a gran altura, interesando así el estudio de la hipoxia hipobárica sobre la espermatogénesis.

Para este estudio se utilizaron dos grupos de ratones machos sexualmente maduros: Control (540 metros sobre el nivel del mar (msnm)) y grupo con hipoxia hipobárica simulada crónica (HHSC) (4.600 msnm) expuestos por 8, 16, 24 ó 33 días. Fueron evaluados hematocrito, reticulocitosis, peso de testículos, epidídimos y vesícula seminal; altura del epitelio seminífero, diámetro tubular, recuento y morfología espermática y lipoperoxidación de membranas de espermatozoides y parénquima testicular.

El peso de testículos, epidídimos y vesícula seminal se redujo para empezar a recuperarse a los 33 días. El diámetro tubular y la altura del epitelio se redujeron y luego tendieron a aumentar sin normalizarse. El recuento y la morfología espermáticos fluctaron en el tiempo.

Se puede concluir que la exposición a HHSC induce daño del epitelio seminífero, disminución de la lipoperoxidación en espermatozoides y tejido testicular, y altera la morfología testicular y espermática.

PALABRAS CLAVE: Hipoxia; Lipoperoxidación; Ratón; Testículo.

\section{REFERENCES}

Ali, M. H.; Schlidt, S. A.; Chandel, N. S.; Hynes, K. L.; Schumacker, P. T. \& Gewertz, B. L. Endothelial permeability and IL-6 production during hypoxia: role of ROS in signal transduction. Am. J. Physiol., 277(5 Pt 1):L1057-65, 1999.

Altland, P. D. Effect of discontinuous exposure to $25.000 \mathrm{ft}$. simulated altitude on growth and reproduction of the albino rats. J. Experim. Zoology, 110(1):1-16, 1949.

Bunn, H. F. \& Poyton, R. O. Oxygen sensing and molecular adaptation to hypoxia. Physiol. Rev., 76(3):839-85. 1996.

Bustos-Obregón, E. \& Olivares, A. Efecto de la hipoxia en la reproducción de mamíferos. El hombre y los ecosistemas de montaña. UNESCO, 1982. pp. 37-98.

Cao, R.; Eriksson, A.; Kubo, H.; Alitalo, K.; Cao, Y. \& Thyberg, J. Comparative evaluation of FGF-2-, VEGF-A-, and VEGF-Cinduced angiogenesis, lymphangiogenesis, vascular fenestrations, and permeability. Circ. Res., 94(5):664-70. 2004.
Clermont, Y. Kinetics of spermatogenesis in mammals: seminiferous epithelium cycle and spermatogonial renewal. Physiol. Rev., 52(1):198-236, 1972.

Dadoune, J. P. \& Alfonsi, M. F. Autoradiographic investigation of sperm transit through the male mouse genital tract after tritiated thymidine incorporation. Reprod. Nutr. Dev., 24(6):927-35, 1984.

Dang, C. V. \& Semenza, G. L. Oncogenic alterations of metabolism. Trends Biochem. Sci., 24(2):68-72, 1999.

Eckhart, A. D.; Yang, N. ; Xin, X. \& Faber, J. E. Characterization of the alpha1B-adrenergic receptor gene promoter region and hypoxia regulatory elements in vascular smooth muscle. Proc. Natl. Acad. Sci. USA, 94(17):9487-92, 1997.

Erkkilä, K.; Pentikäinen, V.; Wikström, M.; Parvinen, M. \& Dunkel, L. Partial Oxygen Pressure and Mitochondrial Permeability Transition Affect Germ Cell Apoptosis in the Human Testis. $J$. Clin. Endocrinol. Metab., 84(11):4253-9, 1999. 
Farias, J. G.; Bustos-Obregón, E. \& Reyes, J. G. Increase in testicular temperature and vascularization induced by hypobaric hypoxia in rats. J. Androl., 26(6):693-7, 2005a.

Farias, J. G.; Bustos-Obregón, E.; Orellana, R.; Bucarey, J. L.; Quiroz, E. \& Reyes, J.G. Effects of chronic hypobaric hypoxia on testis histology and round spermatid oxidative metabolism. Andrologia, 37:47-52. 2005b.

Feldser, D.; Agani, F.; Iyer, N.V.; Pak, B.; Ferreira, G. \& Semenza G. L. Reciprocal positive regulation of hypoxia-inducible factor 1alpha and insulin-like growth factor 2. Cancer Res., 59(16): 3915-8, 1999.

Geneser, F. Órganos de la reproducción. En Histología. Sobre bases biomoleculares. $3^{\mathrm{a}}$ Ed. Panamericana, Madrid, 2000. pp 638-63.

Giordano, F. J. \& Jonson, R.S. Angiogenesis: the role of the microenvironment in flipping the switch. Curr. Opin. Genet. Dev., 11(1):35-40, 2001.

Griveau, J. F.; Dumont, E.; Renard, P.; Callegari, J. P. \& Le Lannou, D. Reactive oxygen species, lipid peroxidation and enzymatic defence systems in human spermatozoa. J. Reprod. Fertil., 103(1):17-26, 1995.

Guyton, A. \& Hall, J. Fisiología de la aviación, las grandes alturas y el espacio. En Tratado de Fisiología Médica. $9^{\text {a }}$ Ed. Mc Graw-Hill, Madrid, 1996. pp 591-8.

Hu, J.; Discher, D. J.; Bishopric, N. H. \& Webster, K. A. Hypoxia regulates expression of the endothelin-1 gene through a proximal hypoxia-inducible factor-1 binding site on the antisense strand. Biochem. Biophys. Res., Commun, 245(3):894-9, 1998.

Krishnamachary, B.; Berg-Dixon, S.; Kelly, B.; Agani, F.; Feldser, D.; Ferreira, G.; Iyer, N.; LaRusch, J.; Pak, B.; Taghavi, P. \& Semenza, G. L. Regulation of colon carcinoma cell invasion by hypoxia-inducible factor 1. Cancer Res., 63(5):1138-43, 2003.

Lee, P. J.; Jiang, B. H.; Chin, B. Y.; Iyer, N.V.; Alam, J.; Semenza, G. L. \& Choi, A.M. Hypoxia-inducible factor-1 mediates transcriptional activation of the heme oxygenase- 1 gene in response to hypoxia. J. Biol. Chem., 272(9):5375-81, 1997.

Melillo, E.; Iabichella, L.; Berchiolli, R.; Ferrari, M.; Catapano, G.; Dell'Omo, G. \& Pedrinelli, R. Transcutaneous oxygen and carbon dioxide during treatment of critical limb ischemia with iloprost, a prostacyclin derivative. Int. J. Microcirc. Clin. Exp., 15(2):60-4, 1995.

Monge, C. \& Monge, C. Adaptación de los animales domésticos. Adaptación a las grandes alturas. Arch. Inst. Biol. Andina, 2: $276,1968$.

Moore, C. R. \& Price, D. A study at high and low altitude of reproduction, growth, sexual maturity and organ weights. $J$. Experim. Zoology, 108:171-216, 1948.

Nguyen, S.V. \& Claycomb, W. C. Hypoxia regulates the expression of the adrenomedullin and HIF-1 genes in cultured HL-1 cardiomyocytes. Biochem. Biophys. Res. Commun, 265(2): 382-6, 1999.

Palmer, L. A.; Semenza, G. L.; Stoler, M. H. \& Johns, R. A. Hypoxia induces type II NOS gene expression in pulmonary artery endothelial cells via HIF-1. Am. J. Physiol., 274(2 Pt 1):L2129, 1998 .

Reeves, J. T. \& Weil, J. V. Aclimatación ventilatoria a grandes altitudes. En Enciclopedia de Salud y Seguridad en el Trabajo, Capítulo 37: Presión barométrica, reducción. Organización Internacional del Trabajo, 2001.

Seagroves, T. N.; Ryan, H. E.; Lu, H.; Wouters, B. G.; Knapp, M.; Thibault, P.; Laderoute, K. \& Johnson, R.S. Transcription factor HIF-1 is a necessary mediator of the pasteur effect in mammalian cells. Mol. Cell. Biol., 21(10):3436-44, 2001.

Semenza, G. L. Angiogenesis in ischemic and neoplastic disorders. Annu. Rev. Med., 54:17-28, 2003.

Vigil, P. \& Bustos-Obregón, E. Alkylating agents and mouse spermatogenesis: Effects of a single dose of cylophosphamide. Andrologia, 17(3):276-82, 1985.

Walton, H. \& Urusky, W. The effects of low atmospheric pressure on the fertility of male rabbits. J. Explt. Biol., 23:71-6, 1946.

Wood, J. G.; Johnson, J. S.; Mattioli, L. F. \& Gonzalez, N. C. Systemic hypoxia increases leukocyte emigration and vascular permeability in conscious rats. J. Appl. Physiol., 89(4):15618,2000

Zagórska, A. \& Dulak, J. HIF-1: the knowns and unknowns of hypoxia sensing. Acta Biochimica Polonica, 51(3):563-85. 2004.

Correspondence to :

Prof. Dr. Eduardo Bustos-Obregón

Facultad de Medicina

Universidad de Chile

Independencia 1027

Santiago 7

CHILE

Fone: $56-2-9786473$

Fax : $56-2-2225710$

Email:ebustos@med.uchile.cl

Receiced: 03-05-2006

Accepted: 22-07-2006 